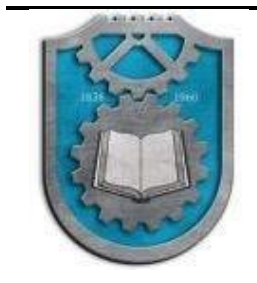

MOBILITY \& VEHICLE

MECHANICS

DOI: $10.24874 / \mathrm{mvm} .2021 .47 .04 .03$

UDC: 614.75

\title{
SOME ASPECTS CONCERNING MANAGEMENT OF ROAD TRANSPORT OF DANGEROUS GOODS USING CONTEMPORARY INFORMATION SYSTEMS
}

\author{
Dragan Vašalić ${ }^{1}$, , Zoran Masoničićc ${ }^{2}$, Saša Milojević ${ }^{3}$, Ivan Ivković ${ }^{4}$, Radivoje Pešić ${ }^{5}$
}

Received in July $2020 \quad$ Revised in September $2020 \quad$ Accepted in September 2020

RESEARCH ARTICLE

\begin{abstract}
In this paper, some aspects concerning the management of road transport of dangerous goods using contemporary information systems

for the sake of energy efficiency increase are presented. The prerequisite condition for optimal utilization of available vehicle fleet and improvement of their operational activities in the domain of road transport of dangerous goods is using sophisticated information systems. Compatibility database presented in this paper, as the central and most significant part of the information system, enables and simplifies the first important task in that manner i.e. obtaining the detailed list of dangerous goods that can be transported in the vehicle intended. Besides that, the analysis of the effects of vehicle constructional features variation onto the mentioned list of dangerous goods allowed for transport can be conducted as well. The information obtained from the compatibility database in conjunction with the geographical information system provides the optimal solution to the transport routes.
\end{abstract}

KEY WORDS: dangerous goods, compatibility database, geographical information system

(C) 2021 Published by University of Kragujevac, Faculty of Engineering

\footnotetext{
${ }^{I}$ Dragan Vašalić, MSc, Universitiy of Belgrade, Institute of Nuclear Sciences "Vinča”, Department for IC engines and Vehicles, M. Petrovića Alasa 12-14, 11351 Belgrade, Serbia, dragan.vasalic@vinca.rs (*Corresponding author)

${ }^{2}$ Zoran Masoničić, MSc, Universitiy of Belgrade, Institute of Nuclear Sciences "Vinča”, Department for IC engines and Vehicles, M. Petrovića Alasa 12-14, 11351 Belgrade, Serbia,

zoran.masonicic@vinca.rs

${ }_{3}^{3}$ Saša Milojević, Mr. Assis. R\&D, University of Kragujevac, Faculty of Engineering, Sestre Janjić 6 , 34000 Kragujevac, Serbia, sasa.milojevic@kg.ac.rs

${ }^{4}$ Ivan Ivković Ph.D. full professor, University of Belgrade, Faculty of Transport and Traffic

Engineering, Vojvode Stepe 305, 11000 Belgrade, Serbia, i.ivkovic@sf.bg.ac.rs

${ }^{5}$ Radivoje Pešić, Ph.D. full prof., University of Kragujevac, Faculty of Engineering, Sestre Janjić 6, 34000 Kragujevac, Serbia, pesicr@kg.ac.rs
} 


\section{NEKI ASPEKTI UPRAVLJANJA DRUMSKIM PREVOZOM OPASNIH TERETA MATERIJA PRIMENOM SAVREMENIH INFORMACIONIH SISTEMA}

REZIME: U ovom radu su predstavljeni neki aspekti upravljanja drumskim prevozom opasnih materija korišćenjem savremenih informacionih sistema u cilju povećanja energetske efikasnosti. Preduslov za optimalno korišćenje raspoloživog voznog parka i poboljšanje njihovih operativnih aktivnosti u domenu drumskog prevoza opasnih materija je primena sofisticiranih informacionih sistema. Baza podataka o kompatibilnosti predstavljena u ovom radu, kao centralni i najznačajniji deo informacionog sistema, omogućava i pojednostavljuje na taj način prvi važan zadatak, odnosno dobijanje detaljne liste opasnih materija koje se mogu prevoziti u predviđenom vozilu. Osim toga, može se izvršiti i analiza uticaja varijacija konstruktivnih karakteristika vozila na pomenuti spisak opasnih materija dozvoljenih za transport. Podaci dobijeni iz baze kompatibilnosti zajedno sa geografskim informacionim sistemom pružaju optimalno rešenje za transportne rute.

KLJUČNE REČI: opasne materije, baza kompatibilnosti, geografski informacioni sistem 


\title{
SOME ASPECTS CONCERNING MANAGEMENT OF ROAD TRANSPORT OF DANGEROUS GOODS USING CONTEMPORARY INFORMATION SYSTEMS
}

\author{
Dragan Vašalić, Zoran Masoničić, Saša Milojević, Ivan Ivković, Radivoje Pešić
}

\section{INTRODUCTION}

Transport and control of transport dangerous goods are very delicate and responsible tasks. Even the smallest mistake can cause catastrophic consequences towards public health and living environment. These issues have been noticed long time ago in all EU countries, so that every union member by using appropriate protocols are achieving dynamic link by amending ADR agreement [1] of road transportation of dangerous goods. Every other year United Nations (ECE) are publishing book with all relevant data of dangerous matters and regulations of transporting each one of them. When it comes to road transportation of dangerous goods, regulations defined in ADR are the first ones to be taken into consideration. ADR defines the very basic requirements for safe transportation of dangerous goods when it comes to road transportation, also as many requests referring to vehicles, goods, classification of goods, compatibility of goods and caring vehicles, ways of packing and analyzing. All of the information includes more than 3,000 dangerous substances that need to be processed during planning and realization of transportation process. These data are part of information system, including compatibility database as the main part which can find its use also in managing transport of dangerous goods. Compatibility database besides the list of dangerous goods also has details of compatibility of dangerous goods with available means of transport based on the aspects of used materials for manufacturing tanks and gaskets. Besides mentioned details, database also contains additional set of information for other constructive characteristics of means of transport. As such, compatibility database gives possibility based on the given requirements, to provide optimal solution, like combination of dangerous goods and carrying vehicles for given transportation route. aing vehicles. Because the carrying vehicles, while doing transportation assignment, get under influence of great number of environmental external factors, but also, they have major influence on life environment, for efficient managing of transportation of dangerous goods, it's necessary to synchronize: transportation process, as the main process, choosing transportation routes and risk evaluation towards life environment, and their influence on profit increase and energetic efficiency of vehicle fleet. Bearing in mind the above mentioned, in this project, the detailed access of managing dangerous goods transportation by using modern information technology, applying geo-data and base of compatibility will be presented. Using modern information systems, gives higher level managers optimal usage of transportation goods and energetic increase of vehicle fleet efficiency and company as well. It will show detailed activity description, mutually dependent managing levels and necessary compliance of transportation process, which includes, vehicle selection, route selection and their impact on environment based on dangerous goods that's been transported.

\section{LITERATURE REVIEW}

Need for modification, of ways for managing dangerous goods transportation, with the goal of rationalization and optimization usage of existing vehicle fleet, has been identified long time ago. According to that, based on many authors $[2,3,4,5]$ its necessary to comply the whole process of transportation which includes route planning, risk assessment, motor vehicles, locating vehicles, etc. Important step while managing dangerous goods 
transportation, besides route planning [6] is maximal usage of transportation capacity [7] which leads to energetic increase of process efficiency. One of the primary process is to obtain dangerous goods compatibility which is transported with transportation goods, so as to say, by using caring vehicles, so that the transportation managing will become efficient and safe with optimal vehicle usage. Many authors claim that for efficient transportation management process, its necessary to synchronize transportation process, which refers to managing, planning and environment process [8,9]. Authors [9] in their research, utilize global information systems with mathematical-analytic planning approach and optimization as a tool to improve managing of dangerous goods transportation and optimal routes selection. Importance of usage modern information systems in route selection especially highlights lower risks of accidents. Authors in research [10] display methodology of managing transportation by using global information system, with the goal to prevent any accidents and emphasize the importance of using modern information systems in selection of the best possible route, to achieve transport managing improvement and risk elimination. By analyzing literature, one can conclude that there are only few related publications, which analyze and combine transportation process, through optimizations of vehicles used - tank vehicles, compatibility between dangerous goods and transporting means and the usage of GIS technologies for achieving the safest and optimal routes.

\section{TRANSPORT OPTIMIZATION USING UNIQUE COMPATIBILITY DATABASE}

During the planning of transportation process, higher level management in the companies define and plane operational plans of vehicle fleet. Key goals, strategies of the companies are, increase of the company profit, optimization, usage of transformational capacity and reducing the risk of accidents. Based on those strategies, transportation process in road transport of dangerous goods needs to be considered as mutual connection between the driver, vehicle, dangerous goods, road infrastructure, law requirements and environment. In order to accomplish set goals, higher management, based on constructive and exploitation characteristics of caring vehicles, characteristics of dangerous goods and road infrastructure plan daily, weekly and monthly operational work goals, all of that in order to maximize the usage of transportation capacity.

Unavoidable steps during transportation planning are:

- Constructive and exploitation characteristics of available vehicles - characteristics which are directly tied to vehicle for dangerous goods transportation, as possible limitations listed in relevant laws and bylaws. (ADR, Regulation UN ECE R105 [11], etc.).

- Basic, minimal requirements vehicles from aspect of dangerous goods that are going to be transported.

- Set of topographic information relevant for organization of transport (location of loading, offload docks, distance between places, topographic details of the area, number of populated places, throw-out transportation route, etc.).

The most important part of informational system includes of non-eclectic database that consists on compatibility between materials used for manufacturing tanks, gaskets and lining and dangerous substances. This database also includes additional data that allows comparison whether certain substance is compatible with a certain tank, i.e. can it be transported in such a tank vehicle. Compatibility database shows interrelations between materials used for cistern manufacturing (and her components) (8 different tank materials and 22 different gaskets materials) and dangerous goods. In this particular case, within 
contemporary information systems

information system of compatibility, the following materials have been taken into consideration.

Table 1 Tank and gaskets materials used for the purpose of compatibility evaluation

\begin{tabular}{|c|c|c|c|}
\hline \multicolumn{2}{|c|}{ Tank materials } & \multicolumn{2}{|c|}{ Gasket and lining materials } \\
\hline \multirow{4}{*}{$\begin{array}{l}\text { Unalloye } \\
\mathrm{d} \text { steel }\end{array}$} & \multirow{4}{*}{$\begin{array}{l}1.0425, \\
\text { P265GH } \\
1.0038 \\
\text { S235JR }\end{array}$} & $\begin{array}{l}\text { PTF } \\
\text { E }\end{array}$ & $\begin{array}{l}\text { polytetrafluoroethyl } \\
\text { ene }\end{array}$ \\
\hline & & FKM & $\begin{array}{l}\text { fluoro-rubber, } \\
\text { vinylidene- } \\
\text { perfluoropropylene } \\
\text {-copolymer }\end{array}$ \\
\hline & & NBR & $\begin{array}{l}\text { butadiene- } \\
\text { acrylonitrile rubber } \\
\text { with } 28 \% \\
\text { acrylonitrile in the } \\
\text { rubber }\end{array}$ \\
\hline & & NR & natural rubber \\
\hline \multirow[b]{2}{*}{$\begin{array}{l}\mathrm{CrNi} \\
\text { steel }\end{array}$} & \multirow[b]{2}{*}{$\begin{array}{l}\text { 1.4306, } \\
\text { X2CrNi19-11 }\end{array}$} & IIR & butyl rubber \\
\hline & & EPD & $\begin{array}{l}\text { ethylene- } \\
\text { propylene-diene } \\
\text { rubber }\end{array}$ \\
\hline \multirow{8}{*}{$\begin{array}{l}\text { CrNiMo } \\
\text { steel }\end{array}$} & \multirow{8}{*}{$\begin{array}{l}\text { 1.4401, } \\
\text { X5CrNiMo17- } \\
12-2 \\
1.4404, \\
\text { X2CrNiMo17- } \\
12-2 \\
1.4571, \\
\text { X6CrNiMoTi1 } \\
7-12-2\end{array}$} & CSM & $\begin{array}{l}\text { chlorosulfonated } \\
\text { polyethylene }\end{array}$ \\
\hline & & $\mathrm{PE}$ & polyethylene \\
\hline & & PP & polypropylene \\
\hline & & $\mathrm{PVC}$ & polyvinyl chloride \\
\hline & & $\begin{array}{l}\text { PVD } \\
\text { F }\end{array}$ & $\begin{array}{l}\text { polyvinylidene } \\
\text { fluoride }\end{array}$ \\
\hline & & IR & isoprene rubber \\
\hline & & SBR & $\begin{array}{l}\text { styrene-butadiene } \\
\text { rubber }\end{array}$ \\
\hline & & $\mathrm{CR}$ & chloroprene rubber \\
\hline \multirow[b]{2}{*}{$\begin{array}{l}\text { Super } \\
\text { steels }\end{array}$} & \multirow{2}{*}{$\begin{array}{l}1.4529, \\
\text { X1NiCrMoCu } \\
\text { N25 } \\
1.4562, \\
\text { X1NiCrMoCu3 } \\
2-28-7 \\
\end{array}$} & $\mathrm{ACM}$ & $\begin{array}{l}\text { acrylate } \\
\text { copolymers }\end{array}$ \\
\hline & & $\mathrm{AU}$ & $\begin{array}{l}\text { polyester urethane } \\
\text { rubber }\end{array}$ \\
\hline \multirow{2}{*}{$\begin{array}{l}\text { Nickel- } \\
\text { based } \\
\text { alloy }\end{array}$} & \multirow{2}{*}{$\begin{array}{l}\text { 2.4605, } \\
\text { NiCr23Mo16 }\end{array}$} & $\mathrm{Q}$ & silicone rubber \\
\hline & & MFQ & $\begin{array}{l}\text { fluorinated silicone } \\
\text { rubber }\end{array}$ \\
\hline \multirow{2}{*}{$\begin{array}{l}\text { Alumini } \\
\text { um }\end{array}$} & \multirow{2}{*}{$\begin{array}{l}\text { EN AW-1060A } \\
\text { Al } 99.5 \%\end{array}$} & $\begin{array}{l}\text { ECT } \\
\text { FE }\end{array}$ & $\begin{array}{l}\text { ethylene } \\
\text { chlorotrifluoroethyl } \\
\text { ene }\end{array}$ \\
\hline & & $\begin{array}{l}\text { HNB } \\
\mathrm{R}\end{array}$ & $\begin{array}{l}\text { hydrated butadiene- } \\
\text { acrylonitrile rubber }\end{array}$ \\
\hline $\begin{array}{l}\text { Alumini } \\
\text { um } \\
\text { alloys }\end{array}$ & $\begin{array}{l}\text { EN AW-5083 } \\
\text { AlMg4,5Mn }\end{array}$ & PFA & $\begin{array}{l}\text { perfluoro alkoxyl } \\
\text { alkane }\end{array}$ \\
\hline Zinc & Zinc & PA & polyamide \\
\hline
\end{tabular}

Besides it, other, very important part of information system is the system containing interrelations between chosen construction parameters of tank vehicles and dangerous goods. This information system contains additional data, which allows comparison whether 
certain dangerous substance is compatible with certain tank vehicle, so as to say whether it can be transported in such tank vehicle. In addition to the previously listed parts, information system includes set of forms which allow new data entry or possible update of existing and detailed information about them can be found in [13]. Besides them, it's very important to say that information system has capability of data entry about vehicle fleet owned by certain company, with detailed technical description of each vehicle. Basic form used for seraching of corresponding compatibility data can be found on the following picture. On this form, there is possibility of choosing tank material, gaskets material, type of charge and discharge system, the existance of safety valve (for ventilation system, exhaust pipe and burst disk) whether isolation system exists, the maximal substance density, etc. In addition to constructive parameters it includes distinction between tanks used in road transport and transport by sea, because requirements when it comes to tank in these two cases can be very different. Also, it is necessary to distinct between normal (chapter 4.3 and 6.8 in ADR) and portable tanks (chapter 4.2 and 6.7 in ADR). In conditions when transport is handled based on requirements stated in $4.3 / 6.8$, the tank code can be chosen optionally while in case with portable tanks, it has to be handled with portable tank instructions. Tank code is alphanumerical code that describes the type of the tank. Firstly, there is a letter that describes the kind of vessel ( $\mathrm{L}$ for substances in liquid condition and $\mathrm{S}$ for substances in solid condition). Second, there is a numeric value for calculation pressure ( $\mathrm{G}$ minimal pressure according to general requirements of $\mathrm{ADR}$ or $1.25,2.65,4,10,15$ or 21 in bars), Third letter serves for identification of charge and discharge system ( $\mathrm{A}=\operatorname{tank}$ with bottomfilling or bottom-discharge openings with two closures, $\mathrm{B}=$ tank with bottom-filling or bottom-discharge openings with three closures, $\mathrm{C}=$ tank with bottom-filling or bottomdischarge openings with only cleaning openings below the surface of the liquid and $\mathrm{D}=\operatorname{tank}$ with bottom-filling or bottom-discharge openings with no openings below the surface of the liquid. On the fourth-place there is letter mark that defines safety valve ( $V=\operatorname{tank}$ with ventilation system only and no device protecting against propagation of flame, $\mathrm{F}=$ tank with ventilation system equipped with device protecting against the propagation of flame, $\mathrm{N}=$ tank with safety valve that is not hermetically closed and $\mathrm{H}=$ hermetically closed tank).

\begin{tabular}{|c|c|c|}
\hline \multicolumn{2}{|l|}{ Pretraga materija } & -0 \\
\hline \multicolumn{3}{|l|}{$\begin{array}{l}\text { Kriterijumi pretrage Nadjene materije } \\
\end{array}$} \\
\hline Oblici transporta- & Pritisak u barima (opciono) & Uslovi kompatibinosti \\
\hline (- železnički / drumski (RID / ADR) & & $\square$ sa evaluaciiom \\
\hline$\square$ pogl 4.3/6.8 $\square$ pogl. 4.2/6.7/6.11 & $\begin{array}{l}\text { Računski pritisak (4.3/6.8) } \\
\text { Test pritisak (4.2/6.7) }\end{array}$ & \multirow{3}{*}{$\begin{array}{l}\text { Test interval } \\
\odot \text { kratak (2,5/3/4 godine) } \\
\bigcirc \text { dug ( } 5 / 6 / 8 \text { godina) }\end{array}$} \\
\hline$\square$ morski (IM0 4.2 / 6.7 / 6.9) & \multirow{3}{*}{$\begin{array}{l}\text { Sigurnosni ventili (opciono) } \\
\text { sa uređajem za ventilaciju } \\
\square \text { sa hvatačem varnica/ekspl. zaštita }\end{array}$} & \\
\hline cisterni & & \\
\hline Tank kod & & \\
\hline Tank instrukcije & obični sigurnosni ventil & \multirow{3}{*}{ 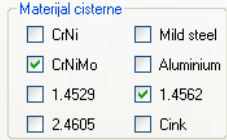 } \\
\hline \multirow{3}{*}{$\begin{array}{l}\text { Transport u konteinerima za rasutit tovar } \\
\square \text { sa ciradom (BK1) } \\
\square \text { zatvoreni konteineri (BK2) }\end{array}$} & $\begin{array}{l}\text { sa rasprskavajućim diskom } \\
\odot \text { bez sigurnosnih uređaja }\end{array}$ & \\
\hline & \multirow{4}{*}{$\begin{array}{l}\text { Otvori sa donie strane [opciono] } \\
\text { sa } 2 \text { zatvarača (A) } \\
\text { sa } 3 \text { zatvarača (B) } \\
\text { samo sa otvorima za čišćcenie (C) } \\
\text { bez otvora (D) }\end{array}$} & \\
\hline & & \multirow{9}{*}{$\begin{array}{l}\text { Materijal zaptivke } \\
\square \text { PTFE } \square \text { FKM } \square \text { CSM } \\
\square \text { NBR } \square \text { NR } \square \text { IIR } \\
\square \text { EPDM } \square \text { PE } \square \text { PP } \\
\square \text { PVC } \square \text { PVDF } \square \text { IR } \\
\square \text { SBR } \square \text { CR } \square \text { ACM } \\
\square \text { AU } \square \mathrm{Q} \quad \square \text { MFQ } \\
\square \text { ECTFE } \square \text { HNBR } \square \text { PFA } \\
\square \text { PA }\end{array}$} \\
\hline Maksimalna gustina materije & & \\
\hline$\square$ maks. gustina $\mathrm{ukg} / \mathrm{l}$ : & & \\
\hline Oprema cisterne & \multirow{2}{*}{$\begin{array}{l}\text { Deblina rezervoara [u odnosu na čelik] } \\
\text { (opciono) }\end{array}$} & \\
\hline Vakumski ventili & & \\
\hline \multicolumn{2}{|l|}{$\square$ sa } & \\
\hline$\square$ pritisak $>=0.05$ bar & & \\
\hline$\square$ pritisak $>=0.21$ bar & $\begin{array}{l}\square 3 \square 4.1 \square 4.2 \square 4.3 \\
\square 5.1 \square 5.2 \square 6.1 \square 6.2\end{array}$ & \\
\hline$\square$ sa hyatačima varnica/ekspl. zaštita & $\begin{array}{l}\square 5.1 \square 5.2 \square 6.1 \square 6.2 \\
\square 7 \square 8 \square 9\end{array}$ & \\
\hline Izolacija & Agregatno stanje & \multirow[b]{2}{*}{ Trazi } \\
\hline$\square$ sa izolaciom & 品isto $\square$ tečno & \\
\hline
\end{tabular}


Some aspects concerning management of road transport of dangerous goods using contemporary information systems

Figure 1 Form used for seraching of corresponding compatibility data

On the following figures search results are displayed. On the Figure 2, there is list of substances which correspond to input criteria, and on the Figure 3, vehicles from database matching the set criterion.

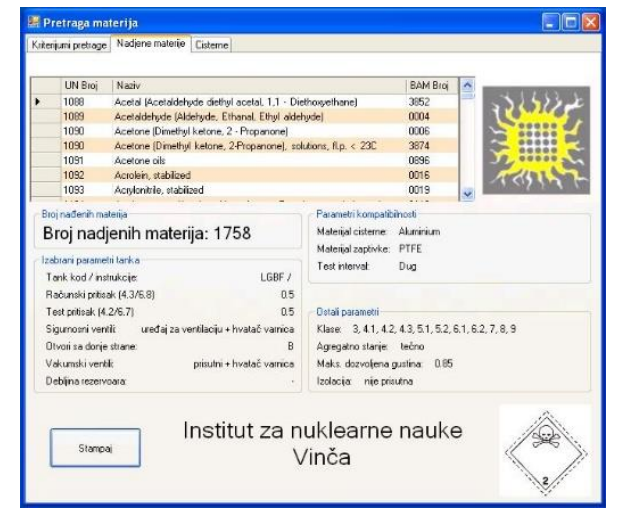

Figure 2 List of substances which correspond search criteria

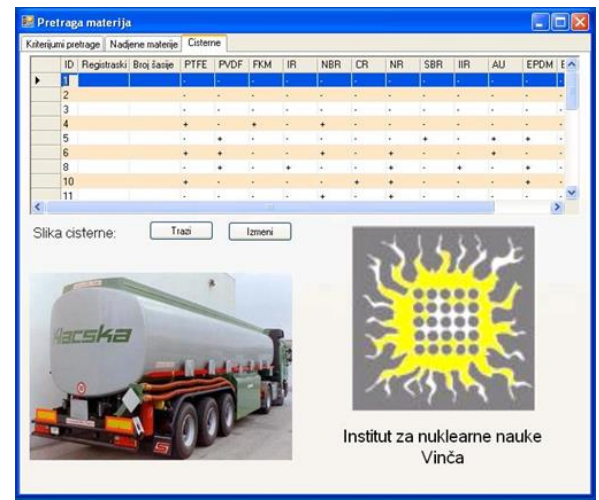

Figure 3 List of vehicles which correspond to search crtieria

Taking into consideration that the essence of energy efficiency of dangerous goods transportation consists from:

- $\quad$ minimalizing the number of vehicles used;

- $\quad$ expansion of the list of dangerous goods that could be transported in available tank vehicles

- $\quad$ using adequate, in particular case original, analysis method avoids incompatibility between materials and substances including the amount of leakages, accidents and negative ecologic effects.

- $\quad$ optimal tank vehicles is chosen for the required dangerous substance.

- optimal modification in case when no appropriate tank vehicle exists.

- $\quad$ optimizing the process of purchasing new vehicles for the given list of dangerous substances intended for the transportation (using analyses of necessary construction parameters and materials for transportation if the dangerous substance considered).

Based on this data, it can be arranged optimization and selection of carrying vehicles for optimal usage of transportation capacity with the final outcome of increasing energy efficiency of the system. For every vehicle in company possession it is possible to gain access of their constructive characteristics, giving centralize managing of companies transportation activities. Based on client's requests, geographical data of loading and unloading docks, the list of dangerous substances transported by companies' vehicles, managers are using database for optimizations and selection of caring vehicles. Dangerous goods transportation from one place to another but with maximum usage of available capacity is complex task, given to managers. Usage of transportation capacity on the way back is additional challenge. It is often necessary to avoid an empty vehicle on the way back, which represents net profit lose, transportation of some other dangerous good is necessary. Using compatibility database with appropriate cartographic support which is 
given by some of existing modern GIS apps allows multiple time saving and forehand planning and usage of carrying vehicles transportation capacity with simultaneous reducing the risk associated with the transportation process.

\section{SDS TEST RESULTS INTERPRETATION}

Main requirement for successful a route analyses of the vehicle for dangerous goods transportation is the most accurate implementation of the road infrastructure with surroundings manly because of the fact that risk levels depends from the region that transportation goes through. Using GIS information system in the field of dangerous goods transportation leads to better planning and managing of the transportation process. The geographic information systems [14] are information system which implements work with databases, maps, satellites and air footage and usage of technologies such as GPS - Global positioning system, video mapping, etc. The geographic information system is the system that uses space information, while the reality in it is represented as series of geographic characteristics, which are defined as two groups of elements. First group of elements are the geographical or locational, which are used as the space reference for the second group, attributes or not-locational elements. The principle of operation of the system is such that the data received from vehicles are stored in databases and it allows real time and the space data display to managers of transport. GIS technologies implements regular databases operations such as searching or statistical analyses, with unique advantages of visualization and space analyses that comes with charts. Models used for managing the transportation process of dangerous goods, represents the part of the implemented model for monitoring and management in real time and the space by using modern GIS technology and basis of compatibility. Advantage of the implemented model of managing, reflects through its multifunctionality, based on the fact that it's used for monitoring, coordination and information in the domain of numerous activities during planning of dangerous goods transportation, connected with exploitation of caring vehicles, road infrastructure, loading and offloading docks.

\section{CONCLUSIONS}

In this paper, the approach for improvement of management of the road transportation of dangerous matter on higher level, using an information system with compatibility database and GIS technology, is presented. Within the implemented transportation management, it has been shown the interrelation between transportation means, like tank vehicles and dangerous goods transported. Possible positive impacts have been displayed towards increase of the energy efficiency by using database of compatibility: optimization of available transporting capacity, minimization of possible occurrence of incompatible combination the tank vehicle - dangerous substance. Besides mentioned improvements, usage of compatibility database has indirect influence on eliminating accidents, and preserving the environment and increasing companies' profit. Further directions of the research will be aimed towards usage of the developed methodology of management, using a basis of compatibility, in other companies in road transportation of dangerous goods, the work monitoring of company and their influence of increasing the energetic efficiency and preserving environment. 


\section{REFERENCES}

[1] European Agreement Concerning the International Carriage of Dangerous Goods by Road ECE/TRANS/275. New York and Geneva: Economic Commission for Europe Inland TransportCommittee; 2018.

[2] Liu, Y., Li, S., Zhang, Y., Xu, S., Chen, M., Song, Z.: “Optimization of Dangerous Goods Recovery Path Base on Improved Ant Colony Algorithm”, International Conference on Robots \& Intelligent System (ICRIS), Changsha, Vol. 1, 2018, pp. 479483. Doi: $10.1109 /$ ICRIS.2018.00126.

[3] Verma, M., Verter V., Zufferey N.: “A bi-objective model for planning and managing rail-truck intermodal transportation of hazardous materials", Transportation research part E: Logistics and Transportation Review, Vol. 48, Iss. 1, 2012, pp.132-149. Doi: 10.1016/j.tre.2011.06.001.

[4] Xie, Y., Lu, W., Wang, W., Quadrifoglio, L.: "A multimodal location and routing model for hazardous materials transportation", Journal of Hazardous Materials, Vol. 227, 2012, pp. 135-141. Doi: 10.1016/j.jhazmat.2012.05.028.

[5] Jiang, Y., Zhang, X., Rong, Y., Zhang, Z.: "A multimodal location and routing model for hazardous materials transportation based on multi-commodity flow model", Procedia-Social and Behavioral Sciences, Vol. 138, 2014, pp. 791-799. Doi: 10.1016/j.sbspro.2014.07.262.

[6] Assadipour, G., Ke, G.Y., Verma, M.: "Planning and managing intermodal transportation of hazardous materials with capacity selection and congestion", Transportation Research Part E: Logistics and Transportation Review, Vol. 76, 2015, pp. 45-57. Doi: 10.1016/j.tre.2015.02.003.

[7] Ruzzenenti, F., Basosi, R.: "Evaluation of the energy efficiency evolution in the European road freight transport sector", Energy Policy, Vol. 37, No. 10, 2009, pp. 4079-4085. Doi: 10.1016/j.enpol.2009.04.050.

[8] Ramachandran, P.: "Vehicle routing problem with load compatibility constraints" IEEE International Conference on Industrial Engineering and Engineering Management, Hong Kong, 2009, pp. 339-343.

[9] Huang, B.: "GIS-based route planning for hazardous material transportation", Journal of Environmental Informatics, Vol. 8, Iss. 1, 2006, pp. 49-57. Doi: 10.3808/jei.200600076.

[10] Verter, V., Kara, B.Y.: "A GIS- based framework for hazardous materials transport risk assessment". Risk Analysis, Vol. 21, No. 6, 2001, pp. 1109-1120. Doi: 10.1111/0272-4332.216179.

[11] Agreement concerning the adoption of uniform technical prescriptions for wheeled vehicles, equipment and parts which can be fitted and/or be used on wheeled vehicles and the conditions for reciprocal recognition of approvals granted on the basis of these prescriptions - Regulation No. 105 - Uniform provisions concerning the approval of vehicles intended for the carriage of dangerous goods with regard to their specific constructional features. Geneva: United Nations, 2010.

[12] Datenbank GEFAHRGUT, Einzelplatzanwendung 12.0. Bundesministerium für Verkehr und digitale Infrastruktur, Bundesanstalt für Materialforschung und-prüfung, 2018.

[13] Masoničić, Z, Jovanović, Z, Živanović, Z, Nikolić, D.: “The interrelationship between tank-vehicles and dangerous substances", XXI Intl. JUMV Automotive Conference SCIENCE \& MOTOR VEHICLES. 2007, Belgrade, ISBN 978-86-80941-31-8. 
[14] Jovanović, V., Đurđev, B., Srdić, Z., Stankov, U.: “Geografski Informacioni Sistemi““. Beograd: Univerzitet Singidunum i Univertzitet u Novom Sadu, 2012. 